\title{
External preference map to evaluate the acceptance of light and diet yogurt preparedus- ingnatural sweeteners
}

\author{
Daiana Aparecida de Carvalho ${ }^{1}$ Gerson de Freitas Silva Valente ${ }^{*}$ \\ Giovana Maria Pereira Assumpção ${ }^{1}$
}

${ }^{1}$ Instituto Federal Sudeste de Minas Gerais (IF SUDESTE MG), Campus Barbacena, Barbacena, MG, Brasil. E-mail: gerson.valente@ ifsudestemg.edu.br. "Corresponding author.

\begin{abstract}
Owing to the high demand for healthier foods, the food industry has been marketing diet and light yogurts. The present study aimed to sensorially evaluate yogurts prepared using natural sweeteners through a simple centroid mixture design with three repetitions at the central point using the preference map methodology. Different formulations were processed using stevia, xylitol, and sucrose in delimited proportions based on the sweetness of the sweetener. A team of tasters was recruited to survey the sensory attributes of the formulations using the check-all-that-apply (CATA) methodology. A product acceptance analysis was also conducted in which 50 consumers evaluated the formulations using a 9-point hedonic scale. After assessing the acceptance, consumers completed the CATA questionnaire. Internal and external preference maps were built using the obtained results. We found high acceptance means (xylitol:stevia:sugar)for F7 (1.0:0:0), F1 (0.5:0:0), and F2 (0:0.5:0.5), which were characterized by a sweet taste, creamy texture, strawberry flavor, fermented milk flavor, and light pink appearance. Formulations with the lowest scores were F6 (0:1.0:0), F3 (0.33:0.33:0.33), and F4(0.5:0.5:0), which were characterized by a residual and bitter taste, astringent sensation, and inconsistent texture.

Key words: principal components analysis, sensory analysis, fermented milk.
\end{abstract}

Mapa de preferência externo para avaliar aceitação de iogurte light e diet elaborados com edulcorantes naturais

RESUMO: Devido à grande procura por alimentos mais saudáveis, as indústrias alimentícias vêm introduzindo no mercado os iogurtes diet e light. O presente estudo teve como finalidade avaliar sensorialmente iogurtes produzidos com edulcorantes naturais através de delineamento de mistura centroide simples com três repetições no ponto central pela metodologia Mapa de preferência. Foram elaboradas diferentes formulações utilizando estévia, xilitol e sacarose em proporções delimitadas considerando o poder adoçante do edulcorante. Uma equipe de provadores foi selecionada para levantamento dos atributos sensoriais dos iogurtes por meio da metodologia Check-All-That-Apply (CATA). Foi ainda efetuada a análise de aceitação do produto em que cinquenta consumidores avaliaram as formulações usando escala hedônica de nove pontos. Após avaliação da aceitação, os consumidores preencheram a ficha do questionário CATA. Com osresultados obtidos foram montados mapas de preferência:interno e externo. Constatou-se maiores médias de aceitação das amostras F7 (1,0:0:0; xilitol:estévia:açúcar), F1 (0,5:0:0,5; xilitol:estévia:açúcar) e F2 (0:0,5:0,5; xilitol:estévia:açúcar) que apresentaram características como gosto adocicado, gosto doce, textura cremosa, sabor polpa de morango, aroma bebida láctea, aparência rosa claro, e as amostras com menores cores foram as F6 (0:1,0:0; xilitol:estévia:açúcar), F3 (0,33:0,33:0,33; xilitol:estévia:açúcar) e F4 (0,5:0,5:0; xilitol:estévia:açúcar)apresentaram características como sabor residual, gosto amargo, sensação adstringente, texturas em consistência.

Palavras-chave: análise de componentes principais, análise sensorial, leite fermentado.

\section{INTRODUCTION}

In Brazil,diet and light food products are classified and regulated into different categories; therefore, they have different purposes. For products to be considered light,according to the provisions of Ordinance SVS/MS N 27/98, they must satisfy the low or light attributes for absolute nutrient content (energy value, sugars, etc.). Diet foods are those intended for patients wanting to consume diets with restricted nutrients. Light foods have a minimum reduction of $25 \%$ in terms of caloric value or the content of some nutrients when compared to a similar one. For products to be considered dietary, they must also comply with the provisions of Ordinance SVS/MS N 29/98.Dietary products can be classified as follows: nutrient-restricted foods, carbohydrate-restricted foods, fat-restricted foods, protein-restricted foods, sodium-restricted foods, and other foods intended for specific purposes. Stevia and xylitol are natural sweeteners that areused as an alternative to sugar in diet and light food products (MUSSATTO \& ROBERTO, 2002; REIS, 2007). Stevia leaf extract is approximately 300 times sweeter than sucrose (FREITAS, 2002). Besides 
being highly soluble in water and alcohol, nonfermentable, and physically and chemically stable, stevia has several industrial applications, mainly in the food industry. Xylitol is extracted from fruits and vegetables, mainly cereals. Because it has a sweetening power and volume similar to that of sucrose, it is preferentially used as a substitute for sucrose; thus, xylitol can be substituted at the same proportion to reach the desired sweetness without affecting the food mass balance. Further, xylitol contains only $2.4 \mathrm{Kcal} / \mathrm{g}$ and does not have an unpleasant residual taste (MUSSATTO \& ROBERTO, 2002).

The addition of sweeteners to produce diet or light yogurt having sensory characteristics similar to those of traditional yogurt should be conducted with caution owing to the diverse chemical structures or conditions of consumption and storage and their interaction with different food properties. Most sweeteners not only have sweetening properties but also other sensory characteristics that are considered undesirable by consumer, such as a persistent sweet taste, bitter taste, and persistent or non-residual taste (REIS, 2007). Substitution of sucrose by other natural sweeteners requires the application of appropriate sensory techniques. For example, it is necessary to determine the concentration of the sweetener to obtain an equivalent sweetness; it is also important to identify which sweetener has sensory characteristics similar tot hose of the product being developed (ESMERINO et al., 2015).

Several advanced techniques in sensory analyses, such as time intensity analysis, parallel factor analysis, principal component analysis, comment analysis, and check-all-that-apply (CATA) methodology, are being implemented in the development of new products by the food industry. These techniques are being used to elaborate internal and external preference maps along with attributes generated by the consumer, which reduces the time and cost for the development of new products (ESMERINO et al., 2017).

Some recent studies have applied these techniques, for example, in evaluating the addition of prebiotics and sweeteners in the development of a chocolate dairy dessert (MORAIS et al., 2014). The formulation was developed using a 9-point hedonic scale for appearance, aroma, flavor, texture, and global acceptance attributes, and a parallel factor analysis and principal component analysis to build the internal preference map. Optimization of the milk dessert formulation simultaneously facilitated the evaluation of consumer acceptance of several sensory attributes.

Sensory analysis techniques that use an elaborated product profile have quickly gained acceptance in the food industry. Techniques that use a direct analysis of the terms generated by the consumer itself are considered easy, do not require any training, and also include information of how a consumer perceives the product. As an example, researchers evaluated different brands of ice cream (FONSECA et al., 2016). Central pivot techniques and comment analysis were effective in characterizing the different chocolate ice cream samples using consumer perception, which had high correlation results. However, they observed that the comment analysis was intuitively performed by the consumers, whereas the central pivot technique presented high analytical and discriminative power, even using consumers, proving this to be a promising technique for routine applications.

The CATA method can be used by consumers to characterize products and to understand the hedonic and sensory characteristics of food products. For each sample, a pre-defined list of sensory descriptors is presented and participants are instructed to select all that apply, which is considered an easy and less time consuming method for the tasters (ARES et al.,2014). Three techniques were used for the characterization of sensory attributes of Greek yogurt:central pivot, CATA, and map of projection (ESMERINO et al., 2017); the authors verified that the techniques used to characterize the product with consumers were efficient.

Application of CATA and intensity scale techniques allowed Minas Frescal cheese to be described in a study aiming to improve products based on consumer perception (OLIVEIRA et al., 2017). Samples of whole cheese (in terms of fat content), low fat cheese, and low lactose content cheese were used. The data obtained were used to reformulate the product based on the consumer's perceptions. The CATA questionnaire identified that only flavor was important for the various cheeses evaluated. Results showed that these techniques used should be considered by cheese producers so that they can adjust the manufacturing based on consumer preference.

In an evaluation of six dairy products in the category of cream and processed cheese (traditional, with the addition of starch, and with the addition of starch and vegetable fat), the CATA technique was used to obtain descriptive attributes (TORRES et al., 2017). The authors concluded that the technique is an alternative method to elaborate on the sensory profile of the product and that the technique was similar to a descriptive and discriminant analysis.

Among the methods used to identify a product's acceptability, most evaluations provide acceptance averages, which do not identify consumers 
or individual segments (RODRIGUES et al., 2013). As such, the importance of elaborating on preference maps is realized, which makes the evaluation of taster behavior in relation to each sample possible.

A preference map can be divided into two categories as follows: internal (when acceptance data are derived from results obtained by affective tests) and external (when a descriptive analysis is provided by a team of trained judges related to acceptance data and the preference of evaluated products)(SILVA; DUARTE; CAVALCANTI-MATA, 2010). As the external preference map enables a comprehensive and detailed explanation of consumer preferences, it becomes an important tool to visualize the behavior of each taster to the analyzed sample(RODRIGUES et al., 2013). The present study applies an external preference mapping methodology to evaluate the effect of the addition of natural sweeteners (stevia and xylitol at different proportions) in the acceptance of liquid yogurts using the CATA technique for evaluating the sensory descriptors of formulations.

\section{MATERIALS AND METHODS}

\section{Preparation of yogurt formulations}

Yogurts were processed with the addition of different sweeteners (sucrose, stevia, and xylitol) at different proportions according to a single centroid blend design with three replicates at the center point, as shown in table 1 (NETO \& SCARMINIO; BRUNS, 2003).Yogurts were prepared following the method proposed by the yeast manufacturer. Sugar (at a proportion of $8 \%$ )was added to the milk (2L) in

Table 1 - Design of simple centroid mixing with three replicates at the central point.

\begin{tabular}{lccc}
\hline Assay & Sucrose & Xylitol & Stevia \\
\hline F1 & 0.500 & 0.500 & 0.000 \\
F2 & 0.500 & 0.000 & 0.500 \\
F3 & 0.333 & 0.333 & 0.333 \\
F3 & 0.333 & 0.333 & 0.333 \\
F3 & 0.333 & 0.333 & 0.333 \\
F4 & 0.000 & 0.500 & 0.500 \\
F5 & 1.000 & 0.000 & 0.000 \\
F6 & 0.000 & 0.000 & 1.000 \\
F7 & 0.000 & 1.000 & 0.000 \\
\hline
\end{tabular}

Zero indicates absence and 1 is the maximum amount of the ingredient (80g xylitol, $80 \mathrm{~g}$ sucrose, or $91 \mathrm{~g}$ nstevia). the formulations before heat treating the raw material at $80^{\circ} \mathrm{C}$ for $30 \mathrm{~min}$. After cooling to $40^{\circ} \mathrm{C}$, yeast (RICA NATA) was added in a lyophilized form along with a lactic culture of Streptococcus thermophiles and Lactobacillus delbruecki subsp. Bulgaricus. The milk was fermented for approximately $12 \mathrm{~h}$ in a thermal box until the acidity of the dough was between $72^{\circ} \mathrm{D}$ and $75^{\circ} \mathrm{D}$. The mass was broken, the strawberry preparation (5\%) of the PROREGI brand and the sweeteners were added (xylitol and stevia at different proportions based on the initial milk volume). The obtained product was then manually packed in polyethylene bottles and stored at $8^{\circ} \mathrm{C}$.

\section{Microbiological analysis}

Microbiological analyses were performed following the method described by SILVA et al. (2017). Coliforms at $35^{\circ} \mathrm{C}$ and $45^{\circ} \mathrm{C}$ were evaluated using the most probable number (MPN) technique. Three series of three tubes were used for sample dilutions of $10^{-1}$, $10^{-2}$, and $10^{-3}$ and results were expressed as MPN.mL ${ }^{-1}$. For molds and yeasts, the surface plating method was used with a potato dextrose agar culture medium and Drigalsky'shandle; one milliliter of the yogurt sample was seeded, followed by incubation at $25^{\circ} \mathrm{C}$ for $5 \mathrm{~d}$. All experiments were performed in duplicate. Results were expressed as colony forming units (CFUs), $\mathrm{mL}^{-1}$.

\section{Sensory analysis}

Sensory analysis was performed with regular consumers of yogurt; students and employees of the Instituto Federal do Sudeste de Minas, Campus Barbacena, who showed an interest in participating were enrolled. Samples were identified by random three digits and were served in plastic containers that were free of any odor.

\section{Acceptance testing}

The formulations were evaluated with 50 tasters in complete blocks balanced following the method of BRASIL (2005) and the overall impression according to the hedonic 9-point scale according to BELSITO et al. (2017). Approximately $20 \mathrm{~g}$ of each formulation was served at $12^{\circ} \mathrm{C}$. Water was served to the consumers to wash their palate between testing of each sample. The analyses were conducted once the free and informed consent of the tasters was obtained.

\section{Sensory attributes}

A pre-selection was performed with 30 consumers following the method described by MINIM (2010). The triangular test was applied in three sessions in which three samples of yogurt 
were offered, two being equal and one being different. Consumers were asked to identify the different sample. Criterion used to select tasters was minimum $60 \%$ accuracy for all tests applied. Descriptive thermology was developed by the Network method (MOSKOWITZ, 1983) with pre-selected tasters aged between 20 and 42 years (10 women and 2 men). In this section, samples of light and traditional yogurts were acquired from local commerce followed by a list of possible attributes. A list of descriptive sensory terms (flavor, taste, aroma, texture, and color) that characterized the sample was prepared. The team, tasters, and a mediator met and, throughan open discussion, chose by consensus the most appropriate and important sensory terms that actually described the yogurt samples. The terms were used to compile the CATA form. Approximately $20 \mathrm{~g}$ of the formulations at $12^{\circ} \mathrm{C}$, which wereunder study, were presented to 50 consumers. Water was served to consumers to wash their palate between each sample. All consumers were asked to record all possible flavor, aroma, texture, taste, and color attributes according to the CATA test sheet (Figure 1) to describe the evaluated product (ARES et al. al., 2014). The sample presentation order was balanced.

\section{Statistical analysis}

The acceptance test results were evaluated using analysis of variance (ANOVA) and a regression analysis using the MINITAB $15^{\circledR}$ software. The attributes chosen by the trained team were used to elaborate the internal and external preference maps through the SENSOMAKER ${ }^{\circledR}$ software. For the preparation of the internal preference map, the samples were used as the abscissa ( $\mathrm{X}$ axis) and the consumers' scores were used as the ordinate (Y axis) in SENSOMAKER ${ }^{\circledR}$. The software preprocesses the data using a correlation matrix. The plot was a vector type. For the preparation of the external preference map, the formulations were used as the $\mathrm{X}$ axis and the frequency of the descriptors obtained with the CATA method were used as the Y axis. Date were pre-processed by SENSOMAKER ${ }^{\circledR}$ through a correlation matrix and plotting vector-type graphs using $\alpha=0.20$, in agreement with the consumers.

\section{RESULTS AND DISCUSSION}

\section{Microbiological analysis}

The nine samples evaluated presented satisfactory results when compared to the limits established by current legislation (BRASIL, 2007), which limits values for indicative samples: Total Coliform less than 100MPN. $\mathrm{mL}^{-1}$, Coliform at $45^{\circ} \mathrm{C}$ was lower than $10 \mathrm{MPN} \cdot \mathrm{mL}^{-1}$ and Yeasts lower than 200CFU.mL $\mathrm{m}^{-1}$ for indicative sample.

\section{Sensory analysis}

Twelve tasters matched $>60 \%$ of the applied tests and were selected to participate in the

\begin{tabular}{|c|c|c|c|c|}
\hline $\begin{array}{l}\text { Name: } \\
\text { Indicate with } \mathrm{X}, \mathrm{t} \\
\text { Sample code }\end{array}$ & most approp & haracteristics to $\mathrm{d}$ & $\begin{array}{r}D \text { ate } \\
\text { pe this yogur }\end{array}$ & mple. \\
\hline $\begin{array}{c}\text { Attribute } \\
\text { Appearance }\end{array}$ & $\begin{array}{l}\text { Attribute } \\
\text { Aroma }\end{array}$ & $\begin{array}{l}\text { Attribute } \\
\text { Texture }\end{array}$ & $\begin{array}{c}\text { Attribute } \\
\text { Taste }\end{array}$ & $\begin{array}{l}\text { Attribute } \\
\text { Flavor }\end{array}$ \\
\hline $\begin{array}{l}\text { ( ) Pink } \\
\text { salmon } \\
\text { ( ) Light } \\
\text { pink } \\
\text { ( ) Presence } \\
\text { of strawberry } \\
\text { pulp } \\
\text { ( ) Absence } \\
\text { of strawberry } \\
\text { pulp }\end{array}$ & $\begin{array}{l}\text { ( ) Fermented } \\
\text { milk } \\
\text { ( ) Artificial } \\
\text { strawberry }\end{array}$ & $\begin{array}{l}\text { ( ) No consistency } \\
\text { ( ) Creamy } \\
\text { ( ) Consistent with } \\
\text { strawberry pulp }\end{array}$ & $\begin{array}{l}\text { ( ) Sweet } \\
\text { ( ) Bitter } \\
\text { taste } \\
\text { ( ) Acid }\end{array}$ & $\begin{array}{l}\text { ( ) Strawberry } \\
\text { pulp } \\
\text { ( ) Residual } \\
\text { Sweetener Flavor } \\
\text { ( ) Astringent } \\
\text { ( ) Sweetish }\end{array}$ \\
\hline
\end{tabular}

Figure 1 - Datasheet specified in the check-all-that-apply test. 
attribute survey. The terms that best characterized the yogurt samples were selected by the team after discussion and consensus (Figure 1). A new results for processed yogurts in which the regression model was statistically significant $(\alpha=0.05)$ are presented in table 2. Results of $t$-test of the coefficients at the $5 \%$ probability level were also significant (Table 3). The mathematical model used was as follows: equation (1)

The coefficients of Eq. (1) indicated that acceptance of the yogurt is better when high proportion of sugar and xylitol is used. As the stevia ratio increases, product acceptance decreases. Results of the evaluation of samples sensory acceptability are graphically represented in Figure 2. Use of xylitol did not promote rejection by the consumers and was within the range of acceptance, unlike the sample with stevia that had a higher index for a minor addition.

Figure 3 graphically represents the internal preference map, high light in the behavior of BRASIL (2007) tasters in relation to sample acceptance for the overall impression atribute. Consumers are Figure 3 graphically represents the internal preference map. Consumers are represented by the vectors and samples are the squares. The closer the vectors and squares, the greater the acceptability of the samples; a greater distance between them indicates a greater rejection by tasters. Samples with a lower proportion of stevia presented a greater acceptance, except for F2 (0.5:0:0.5), which was accepted but was further away from the vectors.

Table 4 shows the absolute frequency of each CATA term used by the tasters to describe the yogurt samples. Data obtained by the CATA method for each descriptor term together with acceptance data of the yogurts were evaluated by means of an external preference map. Forthe external preference map, we used a vector model considering $\alpha=0.20$ with 32 consumers out of a total of 50 , which resulted in a correlation coefficient of $\mathrm{R} 2=0.7975$. This justifies the change that occurred in the acceptance of samples F2 and F4. The first two principal components

Table 2 - Analysis of variance of the global acceptance of yogurts

\begin{tabular}{lcccc}
\hline Source & $\begin{array}{c}\text { Degrees } \\
\text { Freedom }\end{array}$ & $\begin{array}{c}\text { Mean } \\
\text { Square }\end{array}$ & F & $\mathrm{p}$ \\
\hline Regression & 2 & 3.2060 & 6.27 & 0.034 \\
Linear & 2 & 3.2060 & 6.27 & 0.034 \\
Residue & 6 & 0.5117 & & \\
Lack of fit & 4 & 0.7459 & 17.21 & 0.056 \\
Pure error & 2 & 0.0433 & & \\
Total & 8 & & & \\
\hline
\end{tabular}

Table 3 - Coefficient of regression of the global acceptance of yogurts.

\begin{tabular}{lcc}
\hline Predictor & Coefficient & $\mathrm{P}$ \\
\hline Sucrose & 7.836 & 0.00 \\
Xylitol & 7.516 & 0.00 \\
Stevia & 4.916 & 0.00 \\
\hline
\end{tabular}

$\mathrm{R}^{2}=0.676$

(PC1 and PC2) explained $64.29 \%$ of experimental data variance $(37.81 \%$ and $26.48 \%$, respectively).

The attributes of a light pink appearance (APRC), sweetish (GAD), milk flavor aroma (ABL), strawberry flavor (SMOR), sweet taste (GDC), consistency with strawberry pulp (TPM), and creamy texture were identified in the formulations F1, F5, and F7. Sample F4 stood out as having the creamiest texture (TCR). Sample F6 was separated from the vectors; itpresented a residual flavor (SRES), bitter taste (GAM), and texture without consistency (TSC). Sample F3 was classified as astringent (SADST)and F2 had an acid taste (GAC) and an artificial strawberry aroma (AMAT), (Figure 4). CICCONE; DAMY-BENEDETTI (2017) verified acceptance in relation to sweetness, residual taste, overall acceptance, and preference of cola-type soft drinks in the zero, light, and stevia versions. Stevia version comprised 50\% sugar and 50\% stevia and had an acceptance value of seven (moderately liked) for all attributes analyzed. This finding is similar to the acceptability of our F2 formulation.

MAIA et al. (2008) elaborated on and evaluated consumer preference for ice cream formulations (cream, strawberry, and chocolate) sweetened with sucrose and xylitol. Ice cream sweetened with sucrose was preferred over xylitol;however, the acceptability of xylitol was considered high for the general appearance of the ice creams. YUYAMA et al. (2008) developed a "cubiu" (Solanum sessiliflorum Dunal) jelly sweetened with xylitol and observed that its acceptability had similar results.

REIS (2007) studied the elaboration of strawberry light yogurts with different sweeteners, such as sucralose, aspartame, aspartame and acesulfame-k mixture, cyclamate and saccharin mixture, cyclamate, and saccharin and stevia mixture, using the internal preference mapping methodology. Similar product acceptance results were reported for processed yogurt with cyclamate, saccharin, and stevia, which presented with an initial and final bitter taste as the main characteristic and was the least accepted by consumers. BARBOSA (2009) reported similar results regarding the acceptance of light 
Table 4 - Frequency of citation of the descriptor terms used to characterize the yogurt evaluated by the CATA method.

\begin{tabular}{|c|c|c|c|c|c|c|c|c|}
\hline \multirow[t]{2}{*}{ Attributes } & \multirow[t]{2}{*}{ Sigla } & \multicolumn{7}{|c|}{ 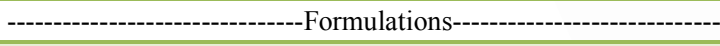 } \\
\hline & & F1 & $\mathrm{F} 2$ & F3 & F4 & F5 & F6 & F7 \\
\hline Light pink appearance & APRS & 19 & 14 & 33 & 31 & 20 & 3 & 24 \\
\hline $\begin{array}{l}\text { Light pink appearance due to presence of strawberry } \\
\text { pulp }\end{array}$ & APRCM & 9 & 14 & 10 & 4 & 7 & 6 & 8 \\
\hline Pink salmon appearance & APRS & 10 & 12 & 11 & 5 & 10 & 8 & 11 \\
\hline Aroma of fermented milk & $\mathrm{ABL}$ & 40 & 33 & 53 & 39 & 40 & 33 & 44 \\
\hline Artificial strawberry aroma & AMAT & 10 & 33 & 22 & 10 & 9 & 17 & 6 \\
\hline Texture without consistency & TSC & 6 & 4 & 17 & 6 & 1 & 11 & 2 \\
\hline Creamy texture & TCR & 32 & 26 & 47 & 28 & 39 & 29 & 33 \\
\hline Consistent with strawberry pulp & TPM & 12 & 20 & 10 & 15 & 10 & 9 & 15 \\
\hline Sweetish & GAD & 31 & 19 & 29 & 24 & 17 & 6 & 26 \\
\hline Sweet taste & GDC & 15 & 25 & 6 & 16 & 30 & 5 & 20 \\
\hline Bitter taste & GAM & 2 & 6 & 25 & 8 & 0 & 31 & 0 \\
\hline Acid taste & GAC & 2 & 45 & 15 & 2 & 3 & 8 & 3 \\
\hline Residual sweetener flavor & SRES & 10 & 10 & 28 & 16 & 2 & 38 & 5 \\
\hline Strawberry flavored pulp & SMOR & 36 & 37 & 24 & 25 & 45 & 5 & 39 \\
\hline Astringent sensation & SADST & 3 & 2 & 22 & 6 & 3 & 6 & 5 \\
\hline
\end{tabular}

F1, xylitol/sucrose; F2, sucrose/stevia; F3, sucrose/stevia/xylitol; F4, xylitol/stevia; F, sucrose; F6, stevia; and F7, xylitol.

yogurt with stevia. UMBELINO (2005) reported the behavior of concentrated mango juice and frozen mango pulp, both reconstituted and sweetened with different sweeteners. A similar sensory characteristic was observed when using stevia as the sweetener; it presented significantly higher attribute averages for residual bitterness, bitterness, and acidity. BRITO (2009) evaluated the sensory behavior of
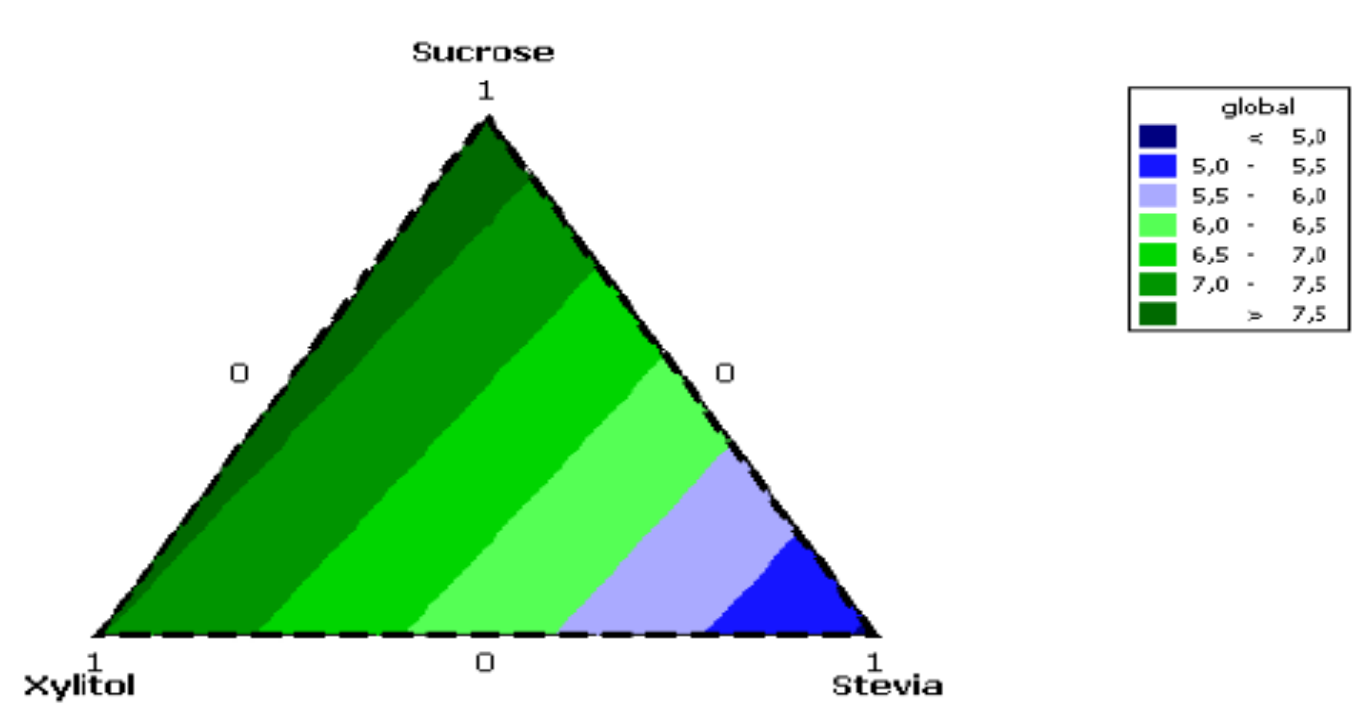

Figure 2 - Graphic representation of the global acceptance of yogurt formulations. 


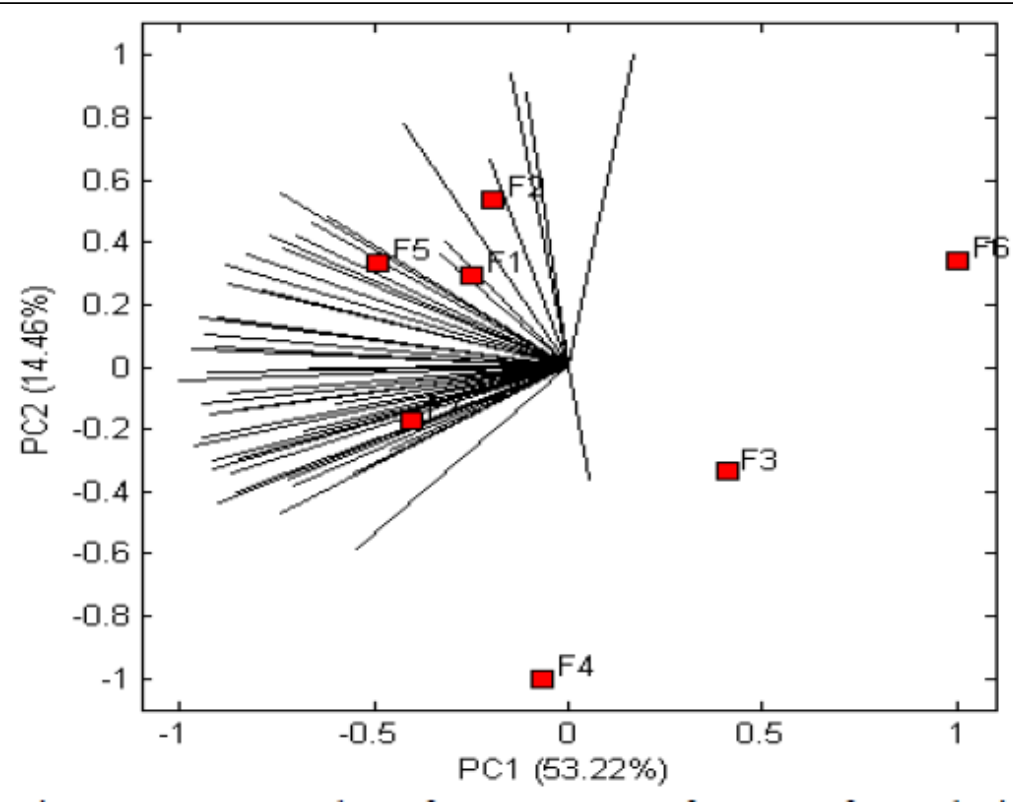

Figure 3 - Internal preference map of yogurt formulations with different sweeteners. F1, xylitol/sucrose; F2, sucrose/stevia; F3, sucrose/ stevia/xylitol; F4, xylitol/stevia; F5, sucrose; F6, stevia; and F7, xylitol.

different sweeteners in a guava pulp light drink (guava nectar) using different sweeteners. Stevia has a distinct behavior, presenting with a sweet taste, bitter taste, residual sweetness, residual bitterness and aroma, and a characteristic herb flavor, thereby resulting in a lower acceptance rate.

The use of the simple centroid mixture design with three replicates at the central point allowed us to define the sensory attributes of the formulations; together with the CATA technique,

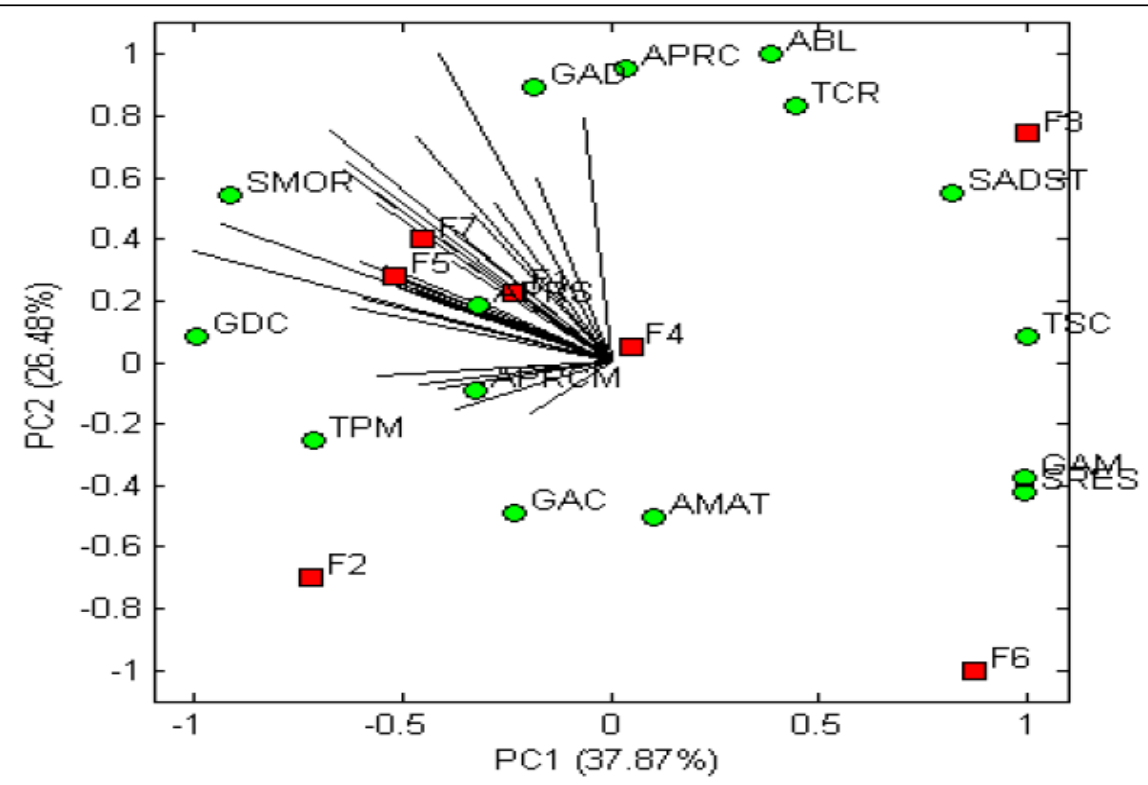

Figure 4 - External preference map for yogurt formulations. F1, xylitol/sucrose; F2, sucrose/stevia; F3, sucrose/stevia/xylitol; F4, xylitol/stevia; F5, sucrose; F6, stevia; and F7, xylitolSRES= Residual Sweetener Flavor; GAM= Bitter taste; AMAT=Artificial Strawberry Aroma; $\mathrm{GAC}=$ Acid taste TPM= Consistent with strawberry pulp; $\mathrm{APRCM}=$ Appearance light pink presence of strawberry pulp; $\mathrm{TSC}=$ Texture without consistency; $\mathrm{GDC}=$ Sweet taste; $\mathrm{APRS}=$ Appearance pink salmon; $\mathrm{SMOR}=\mathrm{Strawberry}$ flavored pulp; $\mathrm{SADST}=$ Astringent sensation; $\mathrm{TCR}=$ Creamy texture; $\mathrm{GAD}=$ Sweetish; $\mathrm{APRC}=$ Light pink appearance; and $\mathrm{ABL}=\mathrm{Aroma}$ of fermented milk . 
itelucidates how these attributes affect product acceptance. At the same time, the procedure allows to define the proportions of the sweetener mixtures for product acceptance. Results obtained reinforced the evaluation of the sweetening power of sweeteners conducted by ESMERINO et al. (2013), PAIXÃO et al. (2014), and ESMERINO et al. (2015).

Multivariate statistical techniques are very useful for analyzing complex data obtained from consumers or trained tasters. Advanced sensory techniques allow acquisition of relevant information about sensory attributes from the consumer. It is worth mentioning that the descriptors obtained from the consumer depend on several factors, because they are complex interactions between the product and the consumer, including consumer personality and previous familiarity and experience with the product (GAZE et al., 2015; JANIASKI et al. 2016).

The CATA methodology is a technique that has been used to gather information about the perception of consumers regarding the sensory characteristics of a product. The CATA questionnaire format allows consumers to choose all possible attributes to describe the product from a list. The terms in the list can be generated by a panel of trained evaluators or by a group of consumers. As the method responses are directly linked to the consumer's perception of product characteristics, these responses can be used to optimize product acceptance. The CATA methodology is efficient for describing and discriminating among products, and its main advantages are the simplicity and speed at which the analyses are conducted. Studies comparing its efficiency with the use of trained evaluators report high correlations among the evaluations, which evidenced that consumers are able to evaluate sensory attributes in a similar way. The main limitation is that the attribute intensityis not quantified, i.e., it is not possible to select a lower power of discrimination when the samples have small differences in attribute intensity (ALCANTARA; FREITAS-SÁ, 2018).

\section{CONCLUSION}

Formulations F1 (0.5:0:0.5) and F7 (1.0:0:0) had high acceptance scores, which presented characteristics of sweet taste, creamy texture, strawberry pulp flavor, dairy drink aroma, and light pink appearance. Formulations F6 (0:1.0:0) and F3 (0.33:0.33:0.33) were less accepted because of their characteristics of residual flavor, bitter taste, astringent mouth feel, and inconsistent texture. Formulations containing xylitol are best suited for the manufacture of strawberry diet and light yogurts, because the sensory profile was the one that most approached traditional yogurt.

\section{ETHICS COMMITTEE}

This study was approved by the Human Research Ethics Committee of Instituto Federal do Sudeste de Minas Gerais (Opinion No. 2,104,000).

\section{ACKNOWLEDGMENT}

To Instituto Federal Sudeste de Minas Gerais.

DECLARATION OF CONFLICT OF
INTEREST

The authors declared no potential conflicts of interest with respect to the research, authorship, and/or publication of this article.

\section{REFERENCES}

ALCANTARA, M. De; FREITAS-SÁ, D. D. G. C. Metodologias sensoriais descritivas mais rápidas e versáteis, uma atualidade na ciência sensorial. Brazilian Journal Food Technology, 2018. v. 21, p. 1-12. Available from: <http://dx.doi.org/10.1590/1981-6723.17916>. Accessed: Apr. 7, 2018. doi:10.1590/1981-6723.17916.

ARES, G. et al. Visual attention by consumers to check-all-thatapply questions: Insights to support methodological development. Food Quality and Preference, 1 Mar. 2014. v. 32, p. 210-220. Available from: <http:/www.sciencedirect.com/science/article/pii/ S0950329313001833>. Accessed: Dec. 21, 2017. doi:10.1016/j. foodqual. 2013.10.006.

BARBOSA, P. B. F. Efeito do edulcorante no perfil sensorial e na aceitação de iogurte natural desnatado batido (diet). 2009. Available from: <http://repositorio.unicamp.br/handle/REPOSIP/254226>. Accessed: Dec. 21, 2017.

BELSITO, P. C. et al. Manufacture of requeijão cremoso processed cheese with galactooligosaccharide. Carbohydrate Polymers, Oct. 15, 2017. v. 174, p. 869-875. Available from: $<$ https://www.sciencedirect. com/science/article/pii/S0144861717307877?via\%3Dihub>. Accessed: Mar. 21, 2018. doi: 10.1016/j.carbpol.2017.07.021.

BRASIL (Ed.). Métodos Físico-Químicos para Análise de Alimentos. 4. ed. Brasília: Ministério da Saúde, 2005.

BRITO, C. A. K. Perfil sensorial de bebida light de polpa de goiaba adoçada com diferentes edulcorantes. Campinas, BRASIL: UNICAMP, 2009. Available from: <http://repositorio.unicamp.br/ handle/REPOSIP/254227>. Accessed: Dec. 21, 2017.

CICCONE, R. F.; DAMY-BENEDETTI, P. C. Aceitabilidade de refrigerantes tipo cola, nas versões light, zero e stévia. Revista Científica, 11 Oct. 2017. v. 1, n. 1. Available from: <http://revistas.unilago.edu.br/ index.php/revista-cientifica/article/view/23>. Accessed: Dec. 21, 2017.

ESMERINO, E.A. et al. The influence of sweeteners in probiotic petit puisse cheese in concentrations equivalent to that of sucrose. Journal of Dairy Science, 1 Sep. 2013. v. 96, n. 9, p. 5512-5521. Available from: $<$ https:// www.sciencedirect.com/science/article/pii/S002203021300461X>. Accessed: Feb. 5, 2018. doi: 10.3168/jds.2013-6616.

ESMERINO, E. A. et al. Consumer-based product characterization using pivot profile, projective mapping andcheck-all-that-apply (CATA): 
A comparative case with Greek yogurt samples. Food Research International, 1 Sep. 2017. v. 99, p. 375-384. Available from: $<$ https:// www.sciencedirect.com/science/article/pii/S0963996917302533>. Accessed: Feb. 5, 2018. doi: 10.1016/j.foodres.2017.06.001.

ESMERINO, E. A. et al. Survival analysis: A consumer-friendly method to estimate the optimum sucrose level in probiotic petit suisse. Journal of Dairy Science, 1 Nov. 2015. v. 98, n. 11, p. 7544-7551. Available from: <https:/www.sciencedirect.com/science/article/ pii/S0022030215006682>. Accessed: Feb. 5, 2018. doi: 10.3168/ jds.2015-9651.

FONSECA, F. G. A. et al.Novel and successfull free comments method for sensory characterization of chocolate ice cream: A comparative study between pivot profile and comment analysis Journal of Dairy Science, 1 May. 2016. v. 99, n. 5, p. 3408-3420. Available from: <https://www.sciencedirect.com/science/article/ pii/S0022030216001685>. Accessed: Feb. 5, 2018. doi: 10.3168/ jds.2015-9982.

FREITAS, M. Q. Características e aceitação sensorial de mortadelas produzidas com carne mecanicamente separada de frango. Viçosa, Brasil: Universidade Federal de Viçosa, 2002. Available from: < http:// www.locus.ufv.br/handle/123456789/8974?show=full>. Accessed: Dec. 21, 2017.

GAZE, L. et al. Preference mapping of dulce de leche commercialized in brazilian markets. Journal of Dairy Science, 2015. v. 98, n. 3, p. 1443-1454. Available from: <http://www.journalofdairyscience.org/ article/S0022-0302(14)00905-9/pdf>. Accessed: Mar. 26, 2018. doi: $10.3168 /$ jds.2014-8470.

JANIASKI, D. R. et al. Strawberry-flavored yogurts and whey beverages: What is the sensory profile of the ideal product? Journal of Dairy Science, 1 Jul. 2016. v. 99, n. 7, p. 5273-5283. Available from: <http://www.ncbi.nlm.nih.gov/ pubmed/27157581>. Accessed: Mar. 26, 2018.

MAIA, M. C. A. et al.Avaliação do consumidor sobre sorvetes com xilitol consumer evaluation of ice cream with xylitol. Journal of Dairy Science, 2008. v. 28, n. 2, p. 341-347. Available from: $<$ http://www.scielo.br/pdf/cta/v28n2/a11v28n2.pdf $>$. Accessed: Dec. 21, 2017. doi: 10.3168/jds.2015-10097.

MINIM, V. P. R. Análise sensorial: Estudos com consumidores. 2. ed. Viçosa: Editora UFV, 2010.

MORAIS, E. C. et al. Development of chocolate dairy dessert with addition of prebiotics and replacement of sucrose with different high-intensity sweeteners. Journal of Dairy Science, 1 May. 2014. v. 97, n. 5, p. 2600-2609. Available from: <http://www.ncbi. nlm.nih.gov/pubmed/24612793>. Accessed: Feb. 5, 2018. doi $10.3168 /$ jds.2013-7603.

MOSKOWITZ, H. R. Product testing and sensory evaluation of foods: Marketing and R\&D approaches. Westport, Conn., USA: Food \& Nutrition Press, 1983.

MUSSATTO, S. I.; ROBERTO, I. C. Xilitol: Edulcorante com efeitos benéficos para a saúde humana. Revista Brasileira de Ciências Farmacêuticas, Dec. 2002. v. 38, n. 4, p. 401-413. Available from: $<$ http://www.scielo.br/scielo.php?script=sci_arttext\&pid=S151693322002000400003\&lng=pt\&nrm=iso\&tlng=pt $>$. Accessed: Oct. 7 , 2016. doi:10.1590/S1516-93322002000400003.
NETO, B. B.; SCARMINIO, I. S.; BRUNS, R. E. Como fazer experimentos: Pesquisa e desenvolvimento na ciência e na indústria. 2. ed. Campinas: Editora Unicamp, 2003.

OLIVEIRA, E. W. et al. Reformulating Minas Frescal cheese using consumers' perceptions: Insights from intensity scales and check-all-that-apply questionnaires. Journal of Dairy Science, 1 Aug. 2017. v. 100, n. 8, p. 6111-6124. Available from: <https:// www.sciencedirect.com/science/article/pii/S0022030217305234>. Accessed: Feb. 5, 2018. doi: 10.3168/jds.2016-12335.

PAIXÃO, J. A. et al. Influence of temperature and fat content on ideal sucrose concentration, sweetening power, and sweetness equivalence of different sweeteners in chocolate milk beverage. Journal of Dairy Science, 1 Dec. 2014.v. 97, n. 12,p. 7344-7353. Available from: $<$ https:// www.sciencedirect.com/science/article/pii/S0022030214007553>. Accessed: Feb. 5, 2018. doi: 10.3168/jds.2014-7995.

REIS, R. C. Iogurte light sabor morango: Equivalência de doçura, caracterização sensorial e impacto da embalagem na intenção de compra do consumidor. Viçosa, Brasil: Universidade Federal de Viçosa, 2007. Available from: $<\mathrm{http} / /$ www.locus.ufv.br/ handle/123456789/501>. Accessed: Dec. 21, 2017.

RODRIGUES, J. S. Q. et al. Qualidade sensorial de néctares de maracujás BRS Ouro Vermelho produzidos em diferentes sistemas de cultivo. Revista Ceres, Oct. 2013. v. 60, n. 5, p. 595-602. Available from: <http://www.scielo.br/scielo. php?script=sci_arttext\&pid=S0034-737X2013000500001\&lng $=$ pt\&tlng $=$ pt $>$. Accessed: Dec. 21, 2017. doi: 10.1590/S0034737X2013000500001.

SILVA, F. De A. S. E; DUARTE, M. E. M.; CAVALCANTIMATA, M. E. R. M. Nova metodologia para interpretação de dados de análise sensorial de alimentos. Engenharia Agrícola, Oct. 2010. v. 30, n. 5, p. 967-973. Available from: <http:// www.scielo.br/scielo.php? script $=$ sci arttext\&pid $=$ S0100 $69162010000500018 \& \operatorname{lng}=\mathrm{pt} \& \mathrm{nrm}=\mathrm{iso} \& \mathrm{t} \operatorname{lng}=\mathrm{pt}>$. Accessed: Oct. 7, 2016. doi:10.1590/S0100-69162010000500018.

SILVA, N. et al. Manual de métodos de análise microbiológica de alimentos e água. 5. ed. São Paulo: Blucher, 2017.

TORRES, F. R. et al. Rapid consumer-based sensory characterization of requeijão cremoso, a spreadable processed cheese: Performance of new statistical approaches to evaluate check-all-that-apply data. Journal of Dairy Science, 1 Aug. 2017. v. 100, n. 8, p. 6100-6110. Available from: <https://www. sciencedirect.com/science/article/pii/S0022030217305404>. Accessed: Feb. 5, 2018. doi: 10.3168/jds.2016-12516.

UMBELINO, D. C. Caracterização sensorial por analise descritiva quantitativa e analise tempo-intensidade de suco e de polpa de manga (Mangifera indica L.) adoçados com diferentes edulcorantes. [S.1.]: [s.n.], 2005. Available from: $<$ http://repositorio.unicamp.br/handle/REPOSIP/254238>. Accessed: Dec. 21, 2017.

YUYAMA, L. K. O. et al. Desenvolvimento e aceitabilidade de geléia dietética de cubiu (Solanum sessiliflorum Dunal). Food Science and Technology, Dec. 2008. v. 28, n. 4, p. 929-934. Available from: $<$ http://www.scielo.br/scielo.php?script=sci_arttext\&pid=S010120612008000400026\&lng=pt\&nrm=iso\&tlng $=\mathrm{pt}>$. Accessed: Dec. 21, 2017. doi: 10.1590/S0101-20612008000400026. 